\title{
OCHRONA BETONU ZWYKŁEGO PRZED AGRESYWNYM ŚRODOWISKIEM W BUDOWNICTWIE ROLNICZYM
}

\author{
Krzysztof Wiśniewski, Joanna Witkowska-Dobrev ${ }^{\bowtie}$, Marek Dohojda \\ Instytut Inżynierii Lądowej, Szkoła Główna Gospodarstwa Wiejskiego w Warszawie
}

\begin{abstract}
STRESZCZENIE
Celem artykułu jest ocena skuteczności preparatów powłokowych stosowanych do ochrony betonu w wyniku oddziaływania środowiska agresywnego. W pracy zawarto zagadnienia procesu korozji i chemoodporności betonu oraz realną użyteczność rozpatrywania powyższej kwestii. Przedstawiono proces badawczy, który został zastosowany w celu wykazania skuteczności wybranych preparatów. Opisane zostały również stosowane komponenty oraz procedury badawcze. Uzyskane wyniki zostały przeanalizowane w celu wykazania wpływu zastosowanych preparatów na poprawę chemoodporności betonu.
\end{abstract}

Słowa kluczowe: preparaty powłokowe, ochrona powierzchniowa, impregnacja, chemoodporna ochrona betonu

\section{WSTĘP}

Beton jako podstawowy wyrób budowlany narażony jest na niszczące oddziaływanie środowiska, w wyniku czego jego struktura ulega degradacji, co w konsekwencji wpływa na pogorszenie jego właściwości użytkowych. Obecnie podstawowym celem, jaki przyświeca badaniom nad trwałością betonu, jest poprawienie jego właściwości, które pozwala uzyskać trwałość budowanych obiektów na wymaganym poziomie. W ciągu ostatniej dekady stwierdzono wiele przypadków, w których pomimo przestrzegania istniejących przepisów odnośnie wykonawstwa i właściwego doboru materiałowego konstrukcje betonowe nie spełniały założonych wymagań co do ich trwałości (Dohojda, 2011). Przyczyną powyższego stanu było nieuwzględnienie oddziaływania środowiska na beton zgodnie z normą PN-EN 1504-2:2006 (Mehta, 2004).
W celu otrzymania trwałego i odpornego na działania korozyjne betonu należy już na etapie projektowania mieszanki betonowej dokonać odpowiedniego doboru jego składników: głównie kruszywa, cementu i wody, ale także dodatków i domieszek, które wpływają na mikrostrukturę stwardniałego zaczynu cementowego. Procesy, na jakie narażony jest beton, według normy PN-EN 1992-1-1:2008/NA:2018 dzieli się na:

- fizyczne: ścieranie, obciążenie mechaniczne, oddziaływanie mrozu;

- chemiczne: reakcja alkalia-krzemionka; oddziaływania substancji agresywnych - korozja stali zbrojeniowej: karbonatyzacja betonu, chlorki;

- biologiczne: bakterie (utlenianie siarki oraz uwodnionych siarczków do siarczanów) - mięczaki (wydzielanie węglanu amonu).

Zasadniczo $\mathrm{w}$ budownictwie, a zwłaszcza rolniczym, jedną z najbardziej niebezpiecznych korozji

Krzysztof Wiśniewski https://orcid.org/0000-0002-5859-1400; Joanna Witkowska-Dobrev https://orcid.org/0000-0001-6613-5037; Marek Dohojda https://orcid.org/0000-0003-0382-805X

$\otimes_{\text {joanna_witkowska@sggw.pl }}$ 
jest chemiczna (Czarnecki, Broniewski i Henning, 1994), która wywołana jest przez agresywne związki chemiczne zawarte $\mathrm{w}$ gruncie, wodzie gruntowej, ale także $\mathrm{w}$ powietrzu wewnątrz pomieszczeń inwentarskich, odciekach pochodzących z magazynów pasz (silosy na kiszonki).

Wyróżnia się trzy podklasy agresji chemicznej, które odpowiadają środowisku mało, średnio oraz silnie agresywnemu. Definiuje się je, określając charakterystykę chemiczną, która obejmuje zawartość siarczanów, dwutlenku węgla, jonów amonowych i magnezowych, kwasów nieorganicznych: mocne (siarkowy $\mathrm{H}_{2} \mathrm{SO}_{4}$, azotowy $\mathrm{HNO}_{3}$, chlorowodorowy $\mathrm{HCl}$ ), słabe (fosforowy $\mathrm{H}_{3} \mathrm{PO}_{4}$, fluorowodorowy $\mathrm{HF}$, siarkowodorowy $\mathrm{H}_{2} \mathrm{~S}$ ), związki organiczne (fenole, rope naftowa, oleje mineralne, sacharozę, glicerynę), gazy będące bezwodnikami kwasowymi $\left(\mathrm{CO}_{2}, \mathrm{SO}_{3}\right.$, $\mathrm{NO}_{\mathrm{x}}$ ), oraz kwasów organicznych w przypadku wód gruntowych.

W przypadku gruntu pod uwagę bierze się również kwasowość wynikającą z zawartości agresywnego $\mathrm{CO}_{2}, \mathrm{NH}_{4}^{+}, \mathrm{Mg}^{2+}$ oraz zawartości siarczanów (Zybura, Jaśniok i Jaśniok, 2011). Nie wszystkie elementy oraz typy konstrukcji budowlanych narażone są na tak znaczne oddziaływanie agresywnego środowiska, jednak w budynkach rolniczych, zbiornikach na gnojowicę i gnojówkę, silosach na kiszonki jest to zjawisko bardzo powszechne (Nieborowski, 1981; Kijowski, Kopia i Pichór 1998; Zivica i Bajza, 2002; Kobielak i Hutnik 2009).

Obiekty gospodarcze w trakcie eksploatacji nieustannie poddawane sa oddziaływaniu czynników powodujących różnego rodzaju ich uszkodzenia. Szeroko spotykana korozja chemiczna i biologiczna jest np. w silosach na kiszonkę, a także w ściekach produkcji rolniczej, tj.: kompost, gnojówka, uryna (kwas octowy, mlekowy i mrówkowy). Reakcje chemiczne zachodzące $\mathrm{w}$ ramach długotrwałego kiszenia pasz skutkują pojawieniem się m.in. kwasu mlekowego, octowego, propionowego i mrówkowego. Związki chemiczne zawarte w tych substancjach reagują ze składnikami betonu, powodując powstawanie soli, co doprowadza do pogorszenia się właściwości użytkowych tych konstrukcji. W wyniku fermentacji powstaje również znaczna ilość dwutlenku węgla, co doprowadza do przyspieszenia procesu karbonatyza- cji betonu. Inne obiekty rolnicze również znacznie narażone są na działanie tego typu korozji - gnojowica zawiera liczne niebezpieczne związki (m.in. $\mathrm{NH}_{4}{ }^{+}$, $\mathrm{Mg}^{2+}, \mathrm{NO}_{3}^{-}, \mathrm{Cl}^{-}, \mathrm{SO}_{4}{ }^{2-}$, a magazyny na nawozy mineralne poddawane są działaniu np. soli kwasu siarkowego (siarczan potasu, siarczan amonu, siarczan magnezu) (Badowska, Danilecki, i Mączyński, 1974; Nieborowski, 1981).

W agresywnym środowisku o kwaśnym odczynie podstawową reakcją, jaka zachodzi z betonem, jest zobojętnienie wodorotlenku wapnia według reakcji

$$
\mathrm{nCa}(\mathrm{OH})_{2}+2 \mathrm{HnR} \rightarrow+\mathrm{CanR}_{2}+2 \mathrm{nH}_{2} \mathrm{O}
$$

Wynikiem przedstawionej reakcji jest powstawanie trudno rozpuszczalnych lub też łatwo rozpuszczalnych $\mathrm{w}$ wodzie soli wapnia. $\mathrm{W}$ przypadku soli trudno rozpuszczalnych jako wyniki reakcji zobojętnienia są wodorotlenki wapnia. Zniszczenia elementów betonowych odbywa się według dwóch różnych sekwencji. Po pierwsze mogą powstawać sole trudno rozpuszczalne, które wykazują minimalne własności wytrzymałościowe, a także minimalne właściwości wiązania, co skutkuje zmniejszoną wytrzymałością betonu na ściskanie i zginanie. $\mathrm{W}$ drugim wariancie powstają związki o większej objętości niż same substraty reakcji. Prowadzi to w dłuższym etapie do ekspansji, w konsekwencji do mikrospękań, a finalnie do zniszczenia elementu betonowego.

W przypadku soli łatwo rozpuszczalnych pojawia się mechanizm wymywania ich z matrycy cementowej, a co za tym idzie zwiększenie porowatości i przepuszczalności zewnętrznej warstwy betonu. Redukcja ilości zasadowego $\mathrm{Ca}(\mathrm{OH})_{2}$ prowadzi w konsekwencji do obniżenia $\mathrm{pH}$ betonu (Allahverdi i Škvára, 2000; Neville, 2000; Zivica i Bajza, 2001).

Dużym problemem w walce z korozją elementów betonowych i żelbetowych jest równoczesność występowania wielu czynników niszczących i współdziałanie ich, co potęguje destruktywny wpływ. Utrudnia również szczegółową analizę procesu, jakiemu może być poddany dany element (konkretne stężenia poszczególnych czynników). Konstrukcje nie są poddawane wyłącznie działaniu jednego typu agresywnego czynnika, co komplikuje zastosowanie skutecznej metody ochrony. Należy również uwzględnić środowisko i zmiany czynników korodujących, jakie mogą 
wystąpić w przyszłości w trakcie długotrwałej eksploatacji (Czarnecki i in., 1994).

W związku z powszechnością zjawiska, jakim jest korozja betonu, występują pewne metody przeciwdziałania temu procesowi, a mianowicie ochrona powierzchniowa i strukturalna. Ochrona powierzchniowa jest najpopularniejsza i polega na zastosowaniu specjalnych tynków, powłok oraz farb, które uniemożliwiają czynnikowi agresywnemu penetrację w głąb struktury betonu (Czarnecki i in., 1994; Kobielak i Hutnik, 2009). Warto również stosować odpowiednie składy mieszanek betonowych, które poprawić moga jej parametry fizyczne - m.in. zapewnić jak największą szczelność, oraz wykorzystywać cementy o małej zawartości wapnia (Nieborowski, 1981). Ochrona materiałowo-strukturalna polega na stosowaniu m.in. betonów o zwiększonej szczelności, odpowiednio dobranej stali oraz grubszej otuliny, a także na doborze właściwych kruszyw i cementów odpornych na działanie agresywnych substancji chemicznych.

W niektórych przypadkach jedynym rozsądnym rozwiązaniem może okazać się stosowanie droższych betonów polimerowych, które mają znacznie większa chemoodporność niż tradycyjne betony oparte na spoiwie cementowym (Czarnecki i in., 1994).

Przeprowadzone w laboratorium technologii betonów Wydziału Budownictwa i Inżynierii Środowiska SGGW badania próbek miały na celu określenie wpływu różnych sposobów ochrony na minimalizację wpływu czynników chemicznych powodujących korozję powierzchniową betonu zwykłego.

\section{MATERIAtY I METODY}

W budownictwie rolniczym najbardziej narażone na korozje chemiczną są silosy przeznaczone do magazynowania kiszonek. Konieczność ochrony elementów betonowych $\mathrm{w}$ silosach można zapewnić poprzez stosowanie preparatów powłokowych lub ochronę strukturalną. Do celów badania użyty został beton towarowy o klasie C16/20, a ta decyzja podjęta została ze względu na powszechność jego stosowania na placach budów. Według danych producenta ten beton jest zgodny z normami PN-EN 13813:2003, PN-EN 197-1:2012 i PN-EN 206+A1:2016-12 oraz klasyfikuje się go do kategorii CT-C20-F4. Jego wskaźnik w/c wyno- si 0,7 . Masę cementu na $1 \mathrm{~m}^{3}$ zawartości mieszanki przyjęto w ilości $260 \mathrm{~kg}$. Właściwości betonu klasy $\mathrm{C} 16 / 20$ według danych producenta zestawiono $\mathrm{w}$ tabeli 1 - Karta charakterystyki zgodnie z 1907/2006/WE, Artykuł 31, dotyczy produktu: KREISEL - Technika Budowlana Sp. z o.o., BETON C16/20.

Produkt, jakim jest beton towarowy C16/20, można traktować jako beton, ponieważ ma on frakcję żwirową. Należy pamiętać, że przesiew został wykonywany na gotowej mieszaninie, a więc powyższe uziarnienie nie ukazuje wyłącznie kruszywa, ale również spoiwo, które zawiera się w ramach frakcji pyłowej i iłowej, oraz ewentualne dodatki i domieszki (tab. 1, rys. 1).

Badanie wytrzymałości na zginanie betonu zostało przeprowadzone $\mathrm{w}$ trzech seriach na 30 próbkach o wymiarach $40 \times 40 \times 160 \mathrm{~mm}$ (beleczki). Sezonowanie tych próbek odbyło się w środowisku mokrym przez okres 28 dni. Następnie w celu sprawdzenia skuteczności ochrony przed korozja przeprowadzono impregnacje próbek - pierwsza seria impregnowana została szkłem wodnym, druga seria impregnowana żywicą, trzecia seria porównawcza bez impregnacji. Próbki umieszczano na krótki okres 14 dni w roztworze kwasu octowego o stężeniu 10\%. Przyjęcie tak wysokiego stężenia kwasu octowego (dużo wyższego niż występujące w sokach kiszonkowych) było podyktowane przede wszystkim tym, czy istnieje możliwość dokonania szybkiej weryfikacji ochrony powierzchniowej próbek betonowych, zamiast sześciomiesięcznego przetrzymywania $\mathrm{W}$ sokach kiszonkowych, jak to opisał Łęcki (1972). Roztwór kwasu octowego przed umieszczeniem w nim próbek charakteryzował się pH ok. 3 (zgodnie ze skalą dołączoną do papieru lakmusowego - rys. 2). Kolejne badanie wykonano po tygodniu przebywania próbek w roztworze kwasu solnego. Po tygodniu przebywania próbek w roztworze kwasu octowego wartość $\mathrm{pH}$ wynosiła ok. 5. Ostatnie badanie przeprowadzono po dwóch tygodniach przebywania próbek w pojemniku $\mathrm{z}$ roztworem. Po wyjęciu badanych beleczek wartość $\mathrm{pH}$ roztworu wynosiła ok. 6 .

Wykonano badania wytrzymałości na zginanie oraz badanie na ściskanie poszczególnych serii próbek, co pozwoliło określić zmianę wytrzymałości (w MPa i \%) próbek zabezpieczonych i niezabezpieczonych (Wiśniewski i Parzychowski, 2016). 
Tabela 1. Właściwości fizyczne i chemiczne mieszanki betonowej

Table 1. Physical and chemical properties of the concrete mix

\begin{tabular}{|c|c|}
\hline \multicolumn{2}{|c|}{ Wygląd - Appearance } \\
\hline Forma-Form & proszek - powder \\
\hline Kolor - Colour & białawy - whitish \\
\hline Zapach - Smell & bez zapachu - no smell \\
\hline Wartość $\mathrm{pH}$ w $20^{\circ} \mathrm{C}-\mathrm{pH}$ value at $20^{\circ} \mathrm{C}$ & 10-11 (po zmieszaniu z wodą) - after mixing with water \\
\hline \multicolumn{2}{|c|}{ Zmiana stanu - Change of state } \\
\hline $\begin{array}{l}\text { Punkt topienia / Zakres topnienia - Melting point / Melting } \\
\text { range }\end{array}$ & $>1300^{\circ} \mathrm{C}$ \\
\hline Punkt wrzenia / Zakres wrzenia - Boiling point / Boiling range & nie dotyczy - not applicable \\
\hline Temperatura zapłonu - Flash-point & nie dotyczy - not applicable \\
\hline Łatwopalność (stała gazowa) - Flammability (solid, gaseous) & materiał nie jest zapalny - the material is not flammable \\
\hline \multicolumn{2}{|c|}{ Temperatura palenia się - Ignition temperature } \\
\hline Temperatura rozkładu - Decomposition temperature & $>825^{\circ} \mathrm{C}$ w $\mathrm{CaO}$ i $\mathrm{CO}_{2}-$ in $\mathrm{CaO}$ and $\mathrm{CO}_{2}$ \\
\hline Samozapłon - Spontaneous combustion & produkt nie jest samozapalny - the product is not self-igniting \\
\hline Niebezpieczeństwo wybuchu - Danger of explosion & produkt nie grozi wybuchem - the product is not explosive \\
\hline Gęstość - Density & nieokreślna - not definite \\
\hline Gęstość nasypowa w $20^{\circ} \mathrm{C}-$ Bulk density at $20^{\circ} \mathrm{C}$ & $1400-1600 \mathrm{~kg} \cdot \mathrm{m}^{-3}$ \\
\hline \multicolumn{2}{|c|}{ Rozpuszczalność w / mieszalność z - Solubility in / Miscibility with } \\
\hline Woda - Water & nieznacznie rozpuszczalny - slightly soluble \\
\hline $\begin{array}{l}\text { Zawartość rozpuszczalników organicznych - Organic solvents } \\
\text { content }\end{array}$ & $0 \%$ \\
\hline Zawartość ciał stałych - Solids content & $100 \%$ \\
\hline
\end{tabular}

Tabela 2. Zestawienie uziarnienia mieszanki

Table 2. Summary of mix grain size

\begin{tabular}{|c|c|c|c|c|}
\hline \multirow[b]{2}{*}{$\begin{array}{l}\text { Frakcja } \\
\text { Fraction }\end{array}$} & \multirow{2}{*}{$\begin{array}{l}\text { Wymiar boku oczka } \\
\text { kwadratowego } \\
\text { Dimension of the square } \\
\text { mesh side } \\
{[\mathrm{mm}]}\end{array}$} & \multicolumn{3}{|c|}{ Łączna pozostałość na sicie - Total residue on sieve [\%] } \\
\hline & & $\begin{array}{l}\text { przesiew } 1 \\
\text { sifting } 1\end{array}$ & $\begin{array}{l}\text { przesiew } 2 \\
\text { sifting } 2\end{array}$ & $\begin{array}{l}\text { średnia arytmetyczna } \\
\text { arithmetic average }\end{array}$ \\
\hline \multirow{2}{*}{$\begin{array}{l}\text { Frakcja żwirowa } \\
\text { Gravel fraction }\end{array}$} & 4 & 1,0 & 1,1 & 1,1 \\
\hline & 2 & 7,0 & 7,5 & 7,2 \\
\hline \multirow{5}{*}{$\begin{array}{l}\text { Frakcja piaskowa } \\
\text { Sand fraction }\end{array}$} & 1 & 14,2 & 14,0 & 14,1 \\
\hline & 0,5 & 25,0 & 25,1 & 25,1 \\
\hline & 0,25 & 19,0 & 18,0 & 18,5 \\
\hline & 0,125 & 13,6 & 14,2 & 13,8 \\
\hline & 0,063 & 10,3 & 10,0 & 10,2 \\
\hline $\begin{array}{l}\text { Frakcja pyłowa i iłowa } \\
\text { Dust fraction and clays }\end{array}$ & $<0,063$ & 9,3 & 10,1 & 10,0 \\
\hline
\end{tabular}




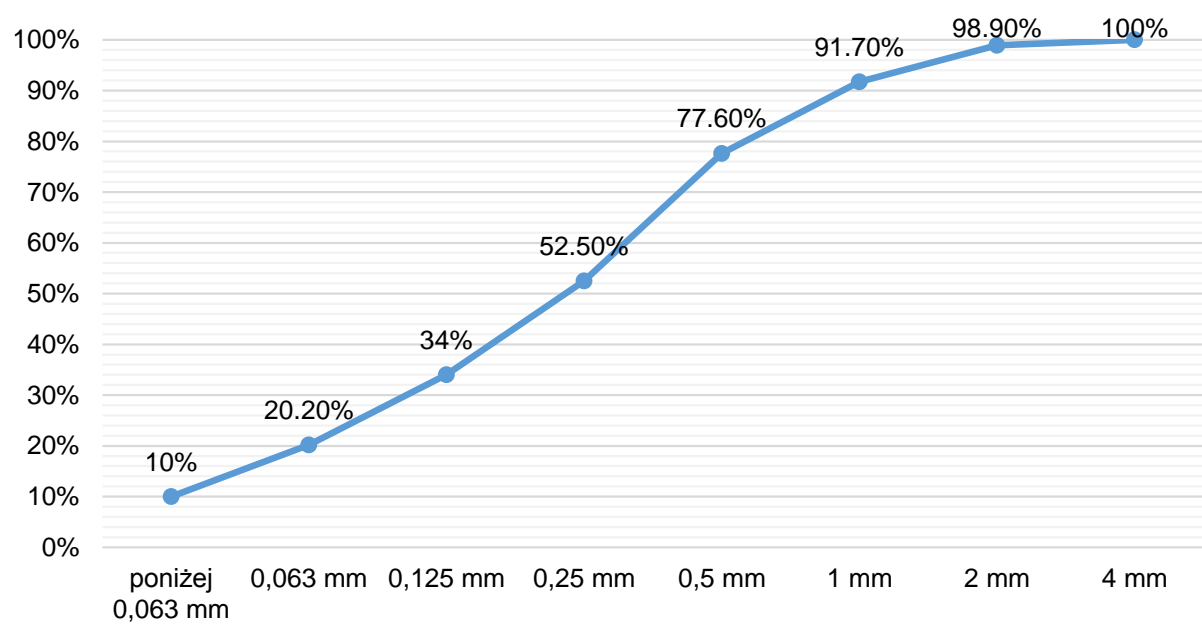

Rys. 1. Krzywa wykonana na podstawie przesiewów przez sita normowe mieszanki użytej do badań

Fig. 1. Curve made on the basis of sieves through standard sieves of the mixture used for testing

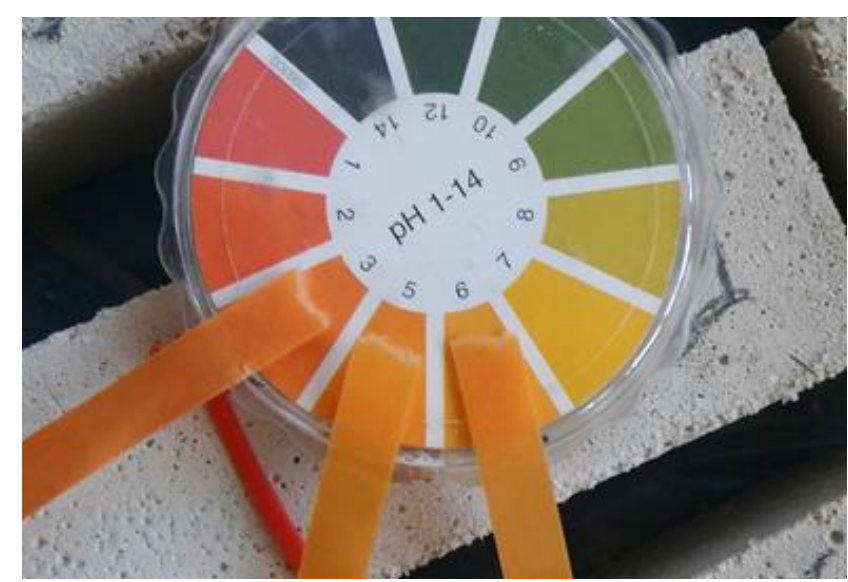

Rys. 2. Przyrównanie papierków lakmusowych ze skalą porównawczą pH

Fig. 2. Comparison of litmus papers with a $\mathrm{pH}$ comparison scale

\section{WYNIKI}

Próbki betonowe poddane procesowi korozji wizualnie różniły się znacznie od próbek wzorcowych. Najbardziej widoczną zmianą były ubytki powstałe na powierzchni betonu i warstwy impregnatu. Po przeprowadzonym procesie oddziaływania środków korozyjnych próbki miały inną barwę oraz znacznie bardziej porowatą powierzchnię. Nawet próbki z jednej serii, wykonane $\mathrm{z}$ takiej samej mieszanki i zaimpregnowane w ten sam sposób, wykazywały różny stopień zniszczenia.
Największą różnorodność wśród próbek w ramach jednej serii wykazywały te zabezpieczone żywicą epoksydową. Pierwszym charakterystycznym elementem był stan warstwy środka impregnującego (rys. 3a i b). W niektórych próbkach zabezpieczonych żywicą ujawniły się niedokładności w przygotowaniu powierzchni próbek przed nałożeniem warstwy ochronnej, która w trakcie badania uległa częściowemu odspojeniu, co spowodowało ekspozycję powierzchni betonu na działanie agresywnego roztworu.

Stopień korozji w poszczególnych miejscach widoczny był szczególnie w przełomie próbek podda- 
nych badaniu wytrzymałości na zginanie. W miejscach, gdzie warstwa żywicy po przeprowadzonym badaniu dokładnie przylegała do powierzchni betonu, grubość produktów korozji była bardzo mała lub prawie niezauważalna. Na fragmenty, gdzie impregnat został odspojony od próbki, wystąiła korozja niewiele mniejszej niż ta, którą można było zaobserwować na próbkach z innych serii poddanych badaniu. $\mathrm{Na}$ tym etapie badań nasuwa się wniosek, że dobre przygotowanie powierzchni próbek (odtłuszczenie, oczyszczenie z pyłu itd.) ma istotny wpływ na adhezję warstwy ochronnej do powierzchni próbek betonowych.
Próbki zaimpregnowane szkłem wodnym miały charakterystyczną osypującą się częściowo warstwę impregnatu zniszczonego $\mathrm{w}$ procesie korozji (rys. 3c). Miała ona białawą barwę i w większości duże rozdrobnienie. W niektórych miejscach na powierzchni próbek impregnat trzymał się dobrze powierzchni betonu i nie wykazywał samoistnego osypywania się. Niezależnie od stanu warstwy ochronnej nie dało się zauważyć zmiany grubości warstwy produktów korozji, co może świadczyć o nikłej skuteczności zastosowanego impregnatu.

$\mathrm{Na}$ próbkach bez zabezpieczenia odnotowano wyraźne ubytki powstałe przez korozję (rys. 4).

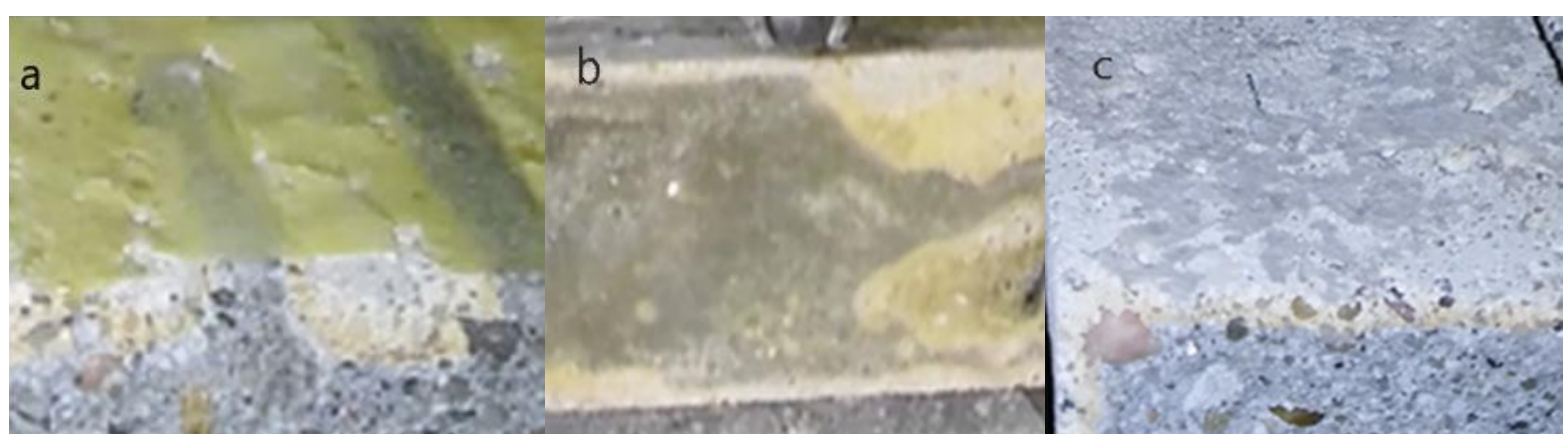

Rys. 3. Próbka zabezpieczona żywicą epoksydową (a i b) i szkłem wodnym (c), na której widać różny stan powłoki ochronnej: a - odspojona i oderwana całkowicie w miejscach jasnoszarego koloru, odspojona w miejscach, gdzie roztwór dostał się pod warstwę ochronną i umożliwił zaistnienie korozji betonu - kolor żółtawy; b - powłoka ochronna uszkodzona w niewielkim stopniu, która nie dopuściła do wystąpienia korozji - kolor ciemnoszary; c - próbka zabezpieczona szkłem wodnym: jasnoszary kolor - pozostałości warstwy szkła wodnego; ciemnoszary - miejsca całkowitego odspojenia powłoki ochronnej

Fig. 3. The sample protected with epoxy resin (a i b) and water glass (c), which shows a various state of the protective coating: a - detached and completely detached in places of light gray color, detached in places where the solution got under the protective layer and allowed concrete corrosion - yellowish; b - protective coating slightly damaged, which did not allow corrosion dark gray color; $\mathrm{c}$ - sample protected with water glass: light gray color - remains of a layer of water glass; dark gray - places of complete detachment of the protective coating

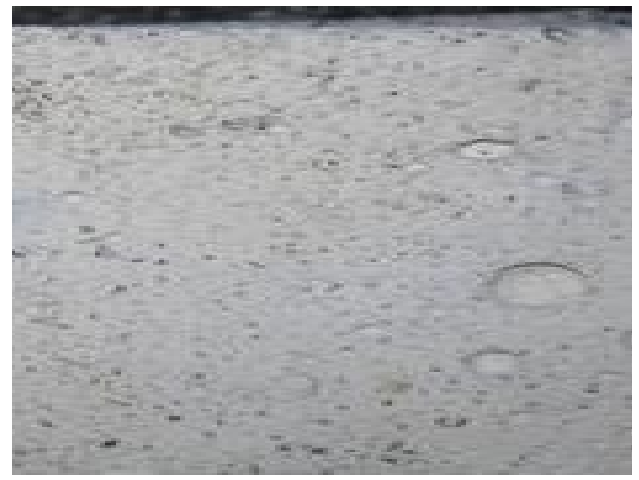

Rys. 4. Powierzchnia próbki niezaimpregnowanej - nieregularna powierzchnia świadczy o ubytkach, które pojawiają się w wyniku ekspozycji na działanie czynnika agresywnego

Fig. 4. Surface of non-impregnated sample - irregular surface indicates defects, which appear as a result of exposure to an aggressive factor 
Powierzchnia próbek miała widoczne ubytki powstałe w wyniku wymywania produktów korozji. Kolor warstwy wierzchniej produktów różnił się ponadto od betonu niepoddanego odziaływaniu agresywnego środowiska. Grubość warstwy efektów korozji bardzo przypominała te, które można było zaobserwować w serii próbek zaimpregnowanych szkłem wodnym.

Beton zabezpieczony żywicą epoksydową wykazywał najmniejsze zmiany oraz znaczną nieregularność warstwy produktów korozji, co może świadczyć o skuteczności takiego zabezpieczenia (tab. 1).

Konsekwencją oddziaływania agresywnego czynnika jest zasadniczo utrata masy próbek betonowych. Ubytek masy jest następstwem wymywania produktów korozji oraz odspajania się kruszywa i zaczynu. $\mathrm{Na}$ rysunku 5 przedstawiono zestawienie średniego ubytku w każdej z wykonanych serii próbek. Wyraźnie widoczna jest zależność między rodzajem zastosowanego środka ochrony powierzchniowej a ubytkiem masy próbki. Badanie wytrzymałości na zginanie zostało przeprowadzone zgodnie z wytycznymi, które są zawarte w normie PN-EN 196-1:2016-07 dotyczącej oznaczania wytrzymałości na ściskanie i opcjonalnie, wytrzymałości na zginanie zaprawy cementowej.

Otrzymane na podstawie badań średnie wartości wytrzymałości betonu na zginanie (tab. 3) odwzorowują stopień korozji próbek w ramach poszczególnych serii. O przydatności powyższej metody decyduje w znaczonym stopniu również współczynnik zmienności, ponieważ określa on, czy uzyskane wyniki są w większości jednorodne czy losowe. Poziom, na jakim prezentuje się wartość współczynnika zmienności w przypadku poszczególnych serii, jest bardzo zbliżony i waha sie od 6,77 do $11,98 \%$. Świadczy to o tym, że badając wytrzymałość próbek na zginanie, uzyskuje się wyniki w znacznym stopniu jednorodne i dobrze korelujące zależność stopnia korozji, jaki można zaobserwować w ramach poszczególnych serii próbek.

Drugim kryterium oceny stopnia korozji betonu było przeprowadzenie badań wytrzymałości na ściskanie badanych próbek. Wytrzymałość na ściskanie betonu jest jedna $\mathrm{z}$ najważniejszych cech tego wyrobu jako materiału konstrukcyjnego i decyduje o jego przydatności w konstrukcji. Uzyskane wyniki badania

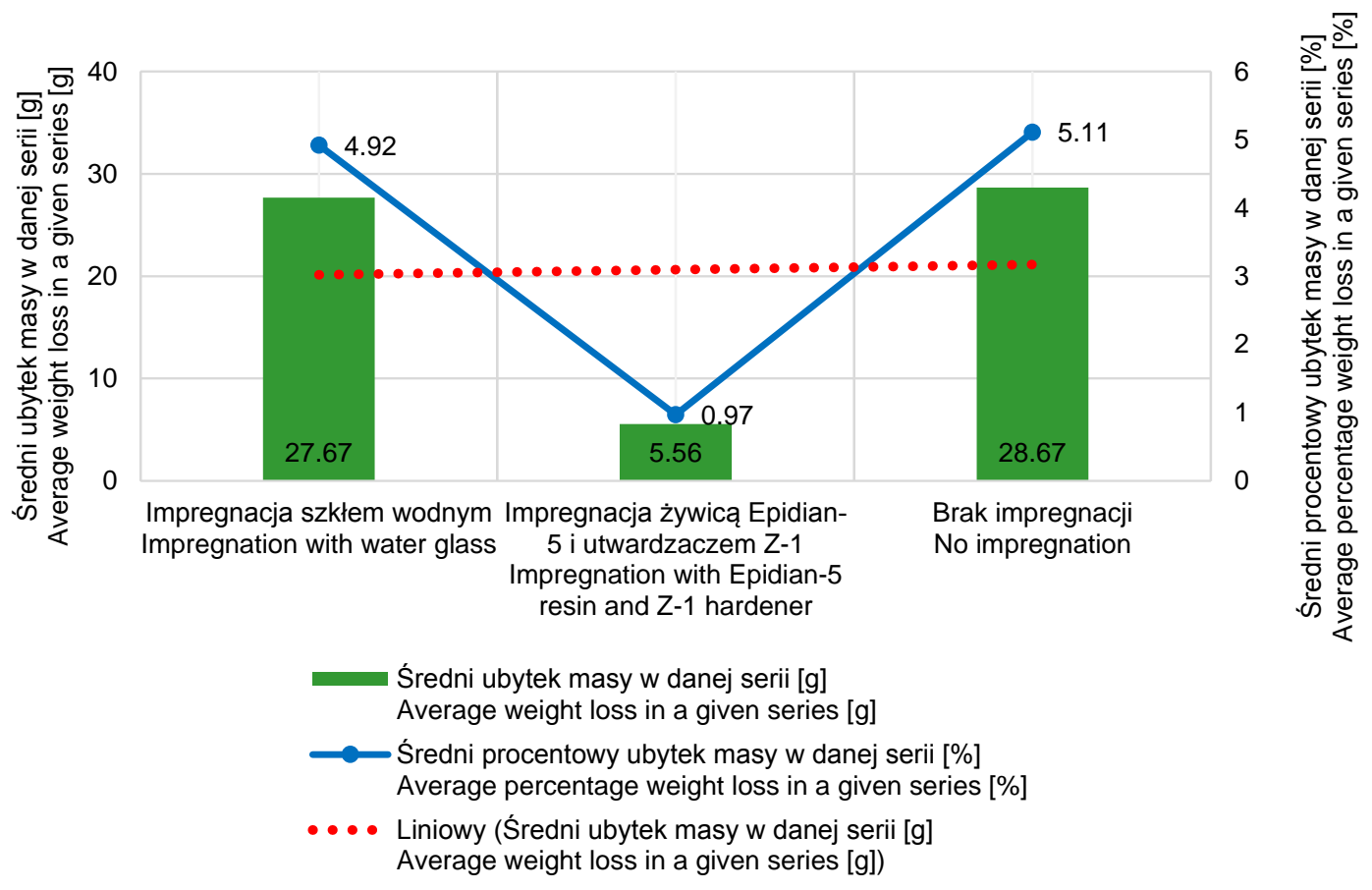

Rys. 5. Zestawienie średnich ubytków masy dla poszczególnych serii

Fig. 5. Juxtaposition of average weight losses in individual series 
Tabela 3. Zestawienie wyników poszczególnych badań

Table 3. Juxtaposition of individual test results

\begin{tabular}{|c|c|c|c|c|c|c|c|c|c|c|c|}
\hline \multirow[t]{2}{*}{$\begin{array}{l}\text { Produkt który zastosowano } \\
\text { w celu wykonania ochrony } \\
\text { powierzchniowej } \\
\text { The product that was used to provide } \\
\text { surface protection }\end{array}$} & 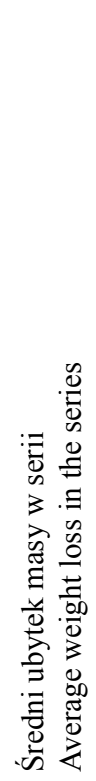 & 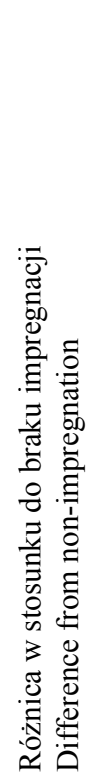 & 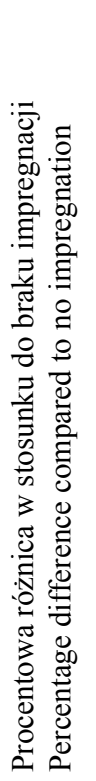 & 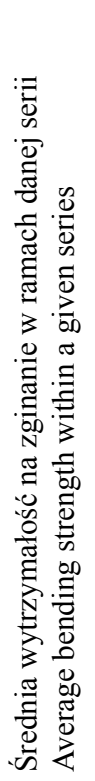 & 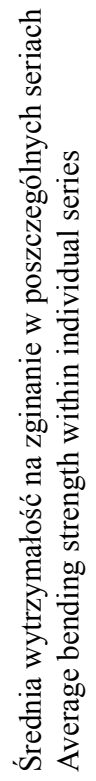 & 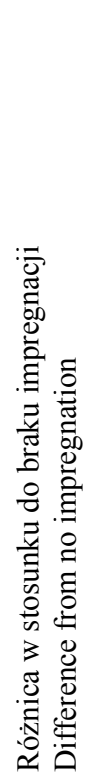 & 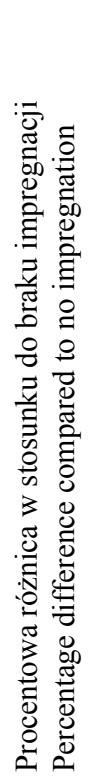 & 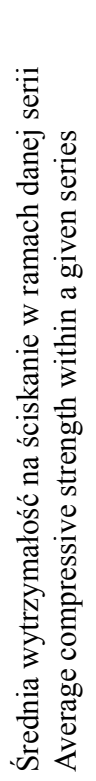 & 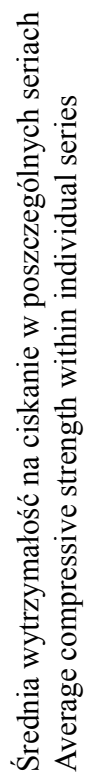 & 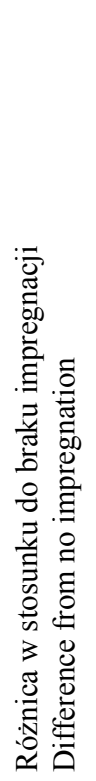 & 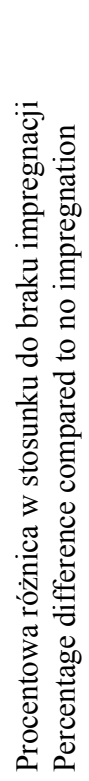 \\
\hline & \multicolumn{2}{|c|}{$\mathrm{g}$} & $\%$ & & $\mathrm{MPa}$ & & $\%$ & & $\mathrm{MPa}$ & & $\%$ \\
\hline $\begin{array}{l}\text { Impregnacja szkłem wodnym } \\
\text { Impregnation with water glass }\end{array}$ & 27,67 & 1,00 & 3 & 3,98 & 0,35 & 0,36 & 10 & 27,07 & 6,58 & 3,58 & 15 \\
\hline $\begin{array}{l}\text { Impregnacja żywicą Epidian-5 } \\
\text { i utwardzaczem Z-1 } \\
\text { Impregnation with Epidian-5 resin } \\
\text { and Z-1 hardener }\end{array}$ & 5,56 & 23,11 & 81 & 5,96 & 0,71 & 2,34 & 65 & 22,6 & 6,61 & $-0,89$ & -4 \\
\hline $\begin{array}{l}\text { Brak impregnacji } \\
\text { No impregnation }\end{array}$ & 28,67 & - & - & 3,62 & 0,25 & - & - & 23,49 & 5,90 & - & - \\
\hline
\end{tabular}

ubytku masy oraz wytrzymałości na ściskanie próbek betonu zostały przedstawione w tabeli 3 .

Analizując wyniki badania wytrzymałości na ściskanie próbek betonowych przy różnych środkach ochrony powierzchniowej, można zauważyć, że próbki zabezpieczone szkłem wodnym wykazują większe wytrzymałości na ściskanie - zaobserwowano wynik wyższy o $15 \%$ niż w ramach próbek niezabezpieczonych, przy średnim ubytku masy na podobnym poziomie. W przypadku wyników w ramach serii zabezpieczonej żywicą epoksydową zaobserwowano jednak spadek wytrzymałości tylko o 4\% w stosunku próbek niezabezpieczonych, ale przy znacznie niższym średnim ubytku masy (5,56 g w porównaniu do 28,67 g próbek niezabezpieczonych). Jak już wcześniej wspo- mniano, zaobserwowano wzrost wytrzymałości betonu na ściskanie w wyniku zastosowania ochrony powierzchniowej ze szkła wodnego. Wartość ta była większa o ok. 3,5 MPa w odniesieniu do próbek niezabezpieczonych oraz 4,47 MPa w stosunku do próbek impregnowanych żywicą epoksydową.

Zastosowanie impregnatów jako środków ograniczających kontakt kwasu z powierzchnią betonu spowodowało zachowanie większej wytrzymałości badanych próbek.

W próbkach zabezpieczonych szkłem wodnym wytrzymałość beleczek na zginanie była znacznie mniejsza, gdyż wykazywały one ślady korozji powierzchniowej i wgłębnej. W świetle opisanych obserwacji chemoodporności stwierdzono, że szkło 
wodne i żywica epoksydowa są najbardziej skuteczne jako warstwy ochronne betonu (tab. 3).

Porównując współczynniki zmienności wytrzymałości betonu na zginanie i ściskanie (rys. 6), wyraźnie można zauważyć, że wyniki pochodzące $\mathrm{z}$ badania wytrzymałości na zginanie są znacznie bardziej jednorodne, a co za tym idzie badanie to lepiej odwzorowuje stopień zniszczenia próbki, a więc i skuteczność zastosowanego środka ochronnego.

Stosowanie metod ochronnych niewątpliwie zwiększy koszty zarówno projektowania, jak i wykonania konstrukcji, jednak pozwoli uniknąć w przyszłości drogich napraw, które mogą spowodować wyłączenia $\mathrm{z}$ użytkowania danych elementów lub całego budynku. Warto zatem przeanalizować dostępne na rynku rozwiązania, aby wybrać te, które będa optymalne dla danego przypadku.

W konstrukcjach narażonych na wyjątkowo agresywną korozję od wewnątrz, ze względu na ich przeznaczenie (w budownictwie rolnym beda to $\mathrm{np}$. silosy na kiszonkę czy zbiorniki na płynne odchody zwierzęce), niezbędne jest zastosowanie dodatkowego zabezpieczania - ochronę powierzchniową (ITB, 2009; Możaryn, Sokalska, i Wójtowicz, 2014). Ochrona powierzchniowa betonu pełni funkcję przeciwdziałania niszczącym procesom poprzez zmniejszenie oddziaływania środowiska, stabilizację parametrów betonu oraz zwiększenie odporności powierzchni betonu. W literaturze i wytycznych wyróżniano kilka podstawowych metod ochrony (ITB, 1998; Możaryn $i$ in., 2014; PN-EN 1504-2:2006; PN-EN 1504-9:2008; PN-86/B-01802:1986).

\section{PODSUMOWANIE}

W tabeli 3 przedstawiono zestawienie wszystkich otrzymanych wyników badań, które ma na celu określenie realnego wpływu wybranych środków ochrony powierzchniowej, jako czynnika zapobiegającego korozji kwasowej. Na podstawie przeprowadzonej oceny skuteczności poszczególnych metod stwierdzono, że najlepsza okazała się ochrona powierzchniowa poprzez impregnację żywicą Epidian-5 i utwardzaczem Z-1.

W tym przypadku uzyskano największą wartość wytrzymałości betonu na zginanie - o $65 \%$ lepsze w stosunku do próbek niezabezpieczonych. Zestawienie wyników badań w celu określenia realnego wpływu wybranych środków ochrony powierzchniowej na przeciwdziałanie skutkom korozji kwasowej pozwoliło uzyskać różnorodne wyniki, które wskazują stopień korozji poszczególnych próbek, a co za tym idzie ich

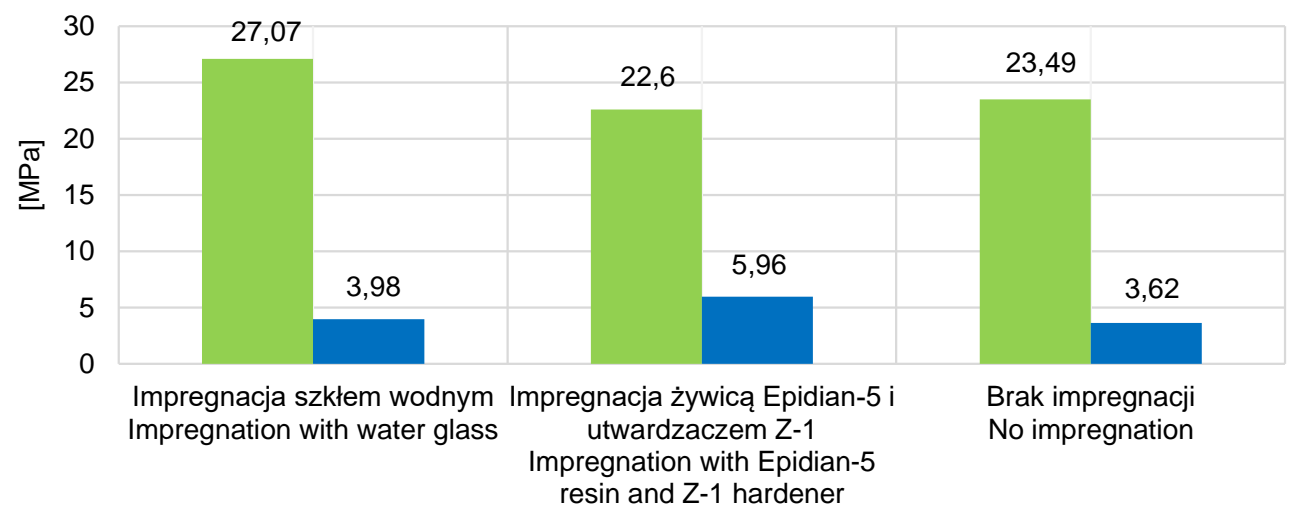

\footnotetext{
Średnia arytmetyczna wytrzymałości na ściskanie próbek w danej serii [MPa] Arithmetic average of compressive strength of samples in a given series [MPa]

—Średnia arytmetyczna wytrzymałości na zginanie w ramach poszczególnych serii [MPa] Arithmetic average of flexural strength within individual series [MPa]
}

Rys. 6. Zestawienie średnich arytmetycznych wytrzymałości na zginanie i ściskanie w poszczególnych seriach badania Fig. 6. Juxtaposition of arithmetic means of individual bending and compression strength testing series 
skuteczność w zastosowanych sposobach ochrony powierzchniowej.

Zaproponowana przez autorów w badaniach szybka metoda określania skuteczności ochrony chemoodpornej powierzchni betonowych (czas ekspozycji 14 dni) oparta jest na wykorzystaniu kąpieli w roztworze 10-procentowego kwasu octowego. Pozwala ona na znacznie szybsze ocenienie skuteczności ochrony powłokowej lub strukturalnej wyrobów betonowych. $\mathrm{W}$ celu pełnej walidacji tej metody wskazane jest przeprowadzenie badań porównawczych metodami szybką i tradycyjną (sześć miesięcy) oceny skuteczności ochrony chemoodpornej przy niższym stężeniu procentowym roztworu kwasu octowego.

Badanie potwierdziło, że powłoki z żywic epoksydowych jako ochrona chemoodporna elementów $\mathrm{z}$ betonu skutecznie zabezpieczają przed korozją powierzchnie stykające się $\mathrm{z}$ substancjami o $\mathrm{pH}<6$. Jest to szczególnie ważne $\mathrm{w}$ przypadku silosów na kiszonki, ale również zbiorników na gnojowice lub gnojówkę, w których są one zakwaszane kwasem siarkowy.

\section{PIŚMIENNICTWO}

Allahverdi, A. i Škvára, F. (2000). Acidic corrosion oh hydrated cement based materials. Part 1 - Mechanism of the phenomenon. Ceramics - Silikáty, 44, 114-120.

Badowska, H., Danilecki, W. i Mączyński, M. (1974). Ochrona budowli przed korozją. Warszawa: Arkady.

Czarnecki, L., Broniewski, T. i Henning, O. (1994). Chemia w budownictwie. Warszawa: Arkady.

Dohojda, M. (2011). Przyczyny powstawania uszkodzeń w podłogach betonowych magazynów wysokiego składowania. Acta Scientiarum Polonorum - Architectura, 10 (2), 43-48.

Instytut Techniki Budowlanej [ITB] (1998). Zabezpieczanie przed korozją konstrukcji betonowych i żelbetowych. Instrukcje, Wytyczne, Poradniki, 351. Warszawa.

Instytut Techniki Budowlanej [ITB] (2009). Ochrona powierzchniowa betonu w warunkach agresji chemicznej. Instrukcje, Wytyczne, Poradniki, 453. Warszawa.

Kijowski, P., Kopia, B. i Pichór, W. (1998). Beton w budowie oczyszczalni ścieków. Kraków: Polski Cement Sp. z o.o.

Kobielak, S. i Hutnik, E. (2009). Projektowanie i budowa betonowych silosów na kiszonki. Wrocław: DWE.
Łęcki, W. (1972). Badanie odporności cementów na działanie kwasów organicznych. Poznań: Rocznik Akademii Rolniczej w Poznaniu.

Mehta, P. K. (2004). High-Performance Concrete, High-Volume fly Ash Concrete for Sustainable Development. In: K. Wang (Ed.), Proceedings of the International Workshop on Sustainable Development and Concrete Technology, Beijing 20-12.05.2004 (strony. 3-14). Ames: Iowa State University.

Możaryn, T., Sokolska, A. i Wójtowicz, M. (2014). Ochrona konstrukcji żelbetowych w obiektach rolniczych w świetle wymagań norm i wytycznych ITB. Izolacje, 19, 56-64.

Neville, A. M. (2000). Wtaściwości betonu. Kraków: Polski Cement.

Nieborowski, H. (1981). Zachowanie się betonów w agresywnych środowiskach obiektów rolniczych. Warszawa: Zakład Graficzny Politechniki Warszawskiej.

PN-86/B-01802:1986. Antykorozyjne zabezpieczenia w budownictwie. Konstrukcje betonowe i żelbetowe. Nazwy i określenia.

PN-EN 13813:2003. Podkłady podłogowe oraz materiały do ich wykonania. Materiały - właściwości i wymagania.

PN-EN 1504-2:2006. Wyroby i systemy do ochrony i napraw konstrukcji betonowych.

PN-EN 1504-9:2008. Wyroby i systemy do ochrony i napraw konstrukcji betonowych. Definicje, wymagania, sterowanie jakością i ocena zgodności. Część 9: Podstawowe zasady dotyczące stosowania wyrobów i systemów.

PN-EN 196-1:2016-07. Metody badania cementu. Część 1: Oznaczanie wytrzymałości.

PN-EN 197-1:2012. Cement. Część 1: Skład, wymagania i kryteria zgodności.

PN-EN 1992-1-1:2008/NA:2018. Eurokod 2: Projektowanie konstrukcji betonu. Część 1: Reguły ogólne i reguły dla budynków. Definicje, wymagania, sterowanie jakością i ocena zgodności. Część 2: Systemy ochrony powierzchniowej betonu.

PN-EN 206+A1:2016-12. Beton. Wymagania, właściwości, produkcja i zgodność.

Wiśniewski, K. i Parzychowski, M. (2016). Wpływ zastosowanych preparatów powłokowych na chemoodporność betonu w budownictwie rolniczym. W W. Romaniuk i H. Jankowska-Huflejt (red.), Problemy intensyfikacji produkcji zwierzęcej z uwzględnieniem standardów Unii Europejskiej i ochrony środowiska (strony 218-223). Falenty: Instytut Technologiczno-Przyrodniczy. 
Zivica, V. i Bajza, A. (2001). Acidic attack of cement based materials-a review: Part 1. Principle of acidic attack. Construction and Building Materials, 15 (8), 331-340.

Zivica, V. i Bajza, A. (2002). Acidic attack of cement-based material - a review: Part 2. Factors of rate of acidic at- tack and protective measures. Construction and Building Materials, 16 (4), 215-222.

Zybura, A., Jaśniok, M. i Jaśniok, T. (2011). Diagnostyka konstrukcji żelbetowych. Tom 2. Badania korozji zbrojenia i właściwości ochronnych betonu. Warszawa: Wydawnictwo Naukowe PWN.

\title{
PROTECTION OF ORDINARY CONCRETE AGAINST AGGRESSIVE CHEMICAL ENVIRONMENT IN AGRICULTURAL CONSTRUCTION
}

\begin{abstract}
The purpose of the article is to evaluate the effectiveness of coating preparations used to protect concrete as a result of aggressive environments. The work included issues related to the corrosion and chemical resistance of concrete and the real utility of handling this issue. A research process is presented that will be used to demonstrate the efficacy of the selected preparations. The components and test procedures used are also described. The results obtained were analysed to demonstrate the efficiency of the preparations used to improve the chemical resistance of concrete.
\end{abstract}

Key words: coating specimens, surface protection, impregnation, chemical resistance of concrete 